\title{
Ongoing downplaying of the carcinogenicity of chrysotile asbestos by vested interests
}

\author{
Xaver Baur ${ }^{1,2^{*}}$ (D) and Arthur L. Frank ${ }^{3}$
}

\begin{abstract}
Industries that mine, manufacture and sell asbestos or asbestos-containing products have a long tradition of promoting the use of asbestos, while placing the burden of economic and health costs on workers and society. This has been successfully done in recent years and decades in spite of the overwhelming evidence that all asbestos types are carcinogenic and cause asbestosis. In doing so, the asbestos industry has undermined the WHO campaign to reach a worldwide ban of asbestos and to eliminate asbestos-related diseases. Even worse, in recent years they succeeded in continuing asbestos mining and consuming in the range of about 1.3 million tons annually. Nowadays, production takes place predominantly in Russia, Kazakhstan and China. Chrysotile is the only asbestos type still sold and represents $95 \%$ of asbestos traded over the last century.

The asbestos industry, especially its PR agency, the International Chrysotile Association, ICA, financed by asbestos mining companies in Russia, Kazakhstan and Zimbabwe and asbestos industrialists in India and Mexico, continues to be extremely active by using slogans such as chrysotile can be used safely.

Another approach of the asbestos industry and of some of its insurance agencies is to broadly defeat liability claims of asbestos victims.

In doing so they systematically use inappropriate science produced by their own and/or by industry-affiliated researchers. Some of the latter were also engaged in producing defense material for other industries including the tobacco industry. Frequent examples of distributing such disinformation include questioning or denying established scientific knowledge about adverse health effects of asbestos. False evidence continues to be published in scientific journals and books.

The persisting strong influence of vested asbestos-related interests in workers and public health issues including regulations and compensation necessitate ongoing alertness, corrections and appropriate reactions in scientific as well as public media and policy advisory bodies.
\end{abstract}

Keywords: Asbestos, Asbestos-related diseases, Mesothelioma, Carcinogenicity, Chrysotile, Compensation, Conflict of interests, Public health policy, Regulations, Vested interests

\footnotetext{
* Correspondence: baur@uke.de

${ }^{1}$ Chair Em. of Occupational Medicine, University of Hamburg, Hamburg, Germany

${ }^{2}$ European Society for Environmental and Occupational Medicine, P.O. Box 370514, D-14135 Berlin, Germany

Full list of author information is available at the end of the article
}

(c) The Author(s). 2021 Open Access This article is licensed under a Creative Commons Attribution 4.0 International License, which permits use, sharing, adaptation, distribution and reproduction in any medium or format, as long as you give appropriate credit to the original author(s) and the source, provide a link to the Creative Commons licence, and indicate if changes were made. The images or other third party material in this article are included in the article's Creative Commons licence, unless indicated otherwise in a credit line to the material. If material is not included in the article's Creative Commons licence and your intended use is not permitted by statutory regulation or exceeds the permitted use, you will need to obtain permission directly from the copyright holder. To view a copy of this licence, visit http://creativecommons.org/licenses/by/4.0/ The Creative Commons Public Domain Dedication waiver (http://creativecommons.org/publicdomain/zero/1.0/) applies to the data made available in this article, unless otherwise stated in a credit line to the data. 


\section{Background}

The ongoing promotion of chrysotile asbestos combined with downplaying its adverse health effects in paying compensation continues to be the driven by commercial interests of the asbestos industry and its insurance systems which apply unsound restrictive compensation practices. This paper refers to publications from these vested interests which appeared in recent years in international journals and a book, respectively. The objective is to document false assumptions and predications from these entities using scientific evidence-based facts.

\section{Questioning of facts, misinterpreting well-established and generally accepted data, manipulating science and unsound changes of diagnostic definitions \\ Promoting chrysotile to the detriment of workers and society with support by affiliated researchers}

For decades, the chrysotile asbestos industry has hired scientists for to create the propaganda that chrysotile is safer than amphibole asbestos types and can be used safely $[1,2]$. Some of these scientists were also engaged in producing defense material for other industries including the tobacco industry [3, 4]. Egilman et al. [5], by evaluating the published and unpublished studies funded by the Quebec Asbestos Mining Association, including those from researchers at McGill University, identified that data were manipulated and unsound sampling and analysis techniques were used to back up the contention that chrysotile was "essentially innocuous". As opposed to the overwhelming scientific evidence, affiliated researchers put forth several myths to suggest that chrysotile was harmless, and contended that the contamination of chrysotile with oils, tremolite, or crocidolite was the source of occupational health risk [5]. Even today, several affiliated scientists minimize or even deny the carcinogenicity potency of chrysotile fibers, especially its potency to cause mesothelioma, for example in mechanics servicing car brakes [6, 7]. Some of these publications were used even by the Canadian government to promote the marketing and sale of asbestos, and have had a substantial effect in inhibiting occupational health protection and compensation. The Asbestos International Association (AIA) and today, its successor, the International Chrysotile Association (ICA), now dominated by the Russian chrysotile industry, is promoting chrysotile especially in developing countries $[1,2]$.

\section{Downplaying chrysotile health hazards even in national studies and in scientific publications}

Similarly to asbestos industry-financed work by some researchers $[8,9]$ with frequently undisclosed ties [10-12] also state-sponsored and/or national studies, e.g. from the UK, postulate that chrysotile does not or only rarely cause mesothelioma and other disorders [13] implying that it can be used safely [14]. This is of special concern in developing countries where safety equipment, training, and oversight are mostly lacking. Gilham and colleagues exclusively rely on asbestos fiber counts measured in lung tissue and use this data as an indicator of asbestos dose decades after exposures although chrysotile has almost disappeared due to its low biopersistence. They did not, however, measure fibers in the pleura, where many fibers translocate. These researchers conclude that there is a linear dose-response relationship between the identified remaining lung asbestos burden (of which 98\% consisted of amphiboles) and the development of mesothelioma, and that the lung burden should be considered a reliable tool to predict future mesothelioma rates in participants born since 1965 . However, only $2 \%$ of the fibers identified in the lung were chrysotile, while chrysotile represented as much as $90 \%$ of the asbestos used in the UK. As opposed to this interpretation there is well established evidence that chrysotile is able to initiate carcinogenic effects before it disappears from the lung [15-23]. It is also worth mentioning that the carcinogenic potency is not related to the remaining asbestos load in the lung after an interim and latency periods of decades [16, 19, 24-27].

Correspondingly, by use of lung fiber analysis and mesothelioma mortality data from the UK, questioning the carcinogenicity of chrysotile was already done by McCormack et al. [28]. These authors estimated the asbestos-related lung cancer risk by relying on incomplete and/or outdated data and also ignoring the translocation and low lung biopersistence of chrysotile; they made the unfounded and disproved conclusion that mesotheliomas in chrysotile-exposed cohorts are due to other asbestos types. For the severe shortcomings and data misinterpretation in this publication see comment published by Lemen et al. [29].

Our major concern refers to an article issued in a scientific pathology journal [30] and very similarly in an etiology section of a well-established and acknowledged book published by the IARC/WHO, i.e. in chapter 2 [31] where chrysotile carcinogenicity is questioned by selective references such as by quotes from Hodgson \& Darnton [32] and Berman \& Crump [33, 34] which exhibit significant misclassification of exposure. See especially page 156 in the WHO/IARC book [31] with highly selected citations: "Some argue that the mesothelial carcinogenicity of chrysotile depends on the level of amphibole fibre tremolite, and that pure chrysotile may not be mesotheliogenic in humans." This has been refuted [35].

Specifically, in this etiology section of chapter 2 of the WHO/IARC (page 156), Attanoos et al. reference publications by Berman \& Crump [34] and Hodgson \& Darnton [32] for the premise that "Mathematical 
modeling suggest that mesothelioma incidents is a linear function of amphibole asbestos dose, and a power function of time since first exposure (Hodgson and Darnton (2000), Berman and Crump,(2008), Peto et al. (1982 [32, 34, 36]. There are marked differences in the potency of different fiber types in inducing mesothelioma: commercial amphibole asbestos (amosite and crocidolite) is 2-3 orders of magnitude more carcinogenic than chrysotile (Hodgson and Darnton 2000, Berman and Crump 2003 [32, 33] ... ..) ... ...However in sufficiently high doses, chrysotile appears to cause lung cancer and very high doses causes mesothelioma in experimental animals". However, animal studies by Wagner et al. [37] and others [38] showed more or comparable figures of cancers from Canadian and other chrysotile sources then from crocidolite.

A related example is "Exposure response coefficients have been estimated for asbestos from approximately 20 epidemiology studies for which adequate exposureresponse data exist. Such coefficients vary widely, however, and the observed variation has not been reconciled. for asbestos exposure" among the cited twenty cohort studies Berman \& Crump homogenized" (Berman \& Crump, Final Draft: Technical Support Document for Protocol to assess asbestos-related risk, at page 1.2) [33].

Correspondingly, Roggli and colleagues from the Duke University Hospital [39], also engaged in Roggli's Private Diagnostic Clinic [PDC, Durham NC 27710; which is not mentioned in the publication], although noting that nearly all of their 325 studied mesothelioma cases with informative data had some asbestos exposure [70\% household contact, $12 \%$ industrial/occupational exposure, 3\% building, and $1 \%$ environmental exposure] stated that in those $43 \%$ where they diagnosed no "objective markers of asbestos exposure" in lungs, that "many of these cases are idiopathic". Roggli et al. again ignored that even low and short time exposure to asbestos causes mesothelioma [40-44], that there is clearly no threshold in causing this disease, and that chrysotile has a low biopersistence. These authors did not measure asbestos fibers in plural tissue and were not able to detect fibers shorter than five micrometres, although there is strong evidence that the latter are also harmful and are carcinogenic [45-47].

The mentioned assumptions of the authors of the aforementioned WHO/IARC book section and the other publication and of Berman and Crumb are not only based on use of selective and outdated data, in addition, inaccurate, unreliable information about the differences in potency of the different types of asbestos fibers are presented. As given in detail in the next paragraph, mesothelioma risk is not only related to initial, rather also to subsequent asbestos exposures; furthermore, several important studies rebut the assumption of major differences between the various asbestos types.

\section{Declining compensation of asbestos victims}

Another aspect of disinformation is to broadly defeat liability claims of asbestos victims. A prominent approach for this is systematically denying mesothelioma causation in chrysotile miners and car mechanics repairing brakes and chrysotile miners by Roggli et al. [6, 48-53]. Similarly, insurance affiliated pathologists of the so-called Mesotheliom-Register in Germany have routinely quantified asbestos bodies or asbestos fibers in lung tissue falsely assuming that chrysotile is biopersistent [54, 55]; low chrysotile amounts or its absence in the lung has been broadly interpreted as evidence for a non-asbestos disorder such as idiopathic lung fibrosis in thousands of cases. There is severe criticism on the latter obviously erroneous findings and false interpretations [56-61]. This Mesotheliom-Register, owned and paid for, respectively, by the German statutory accident insurance institutions, has annually given about one thousand expert opinions on the basis of their monopolistic lung pathohistology and fiber examinations on behalf of the statutory accident insurance institutions; they have used for interpreting their findings the unsound restrictive histological and fiber-count-based asbestosis definition by Roggli et al. [62] which Roggli succeeded in introducing into the Helsinki Criteria [63]. For details of this modification of the CAP/NIOSH asbestosis definition and Roggli's severe conflicts of interest due to his wellpaid support by the asbestos industry see [11, 64-69]. Roggli changed early asbestos-induced lesions of grade 1 asbestosis as defined by $\mathrm{CAP} / \mathrm{NIOSH}$, to grade 0 . Furthermore, and most importantly, without any scientific evidence, Roggli calls for the presence of a certain number of asbestos fibres and/or asbestos bodies in lung tissue as a pathohistological precondition for asbestosis and asbestos-related lung cancer [56, 68]. This latter requirement is especially inappropriate for chrysotile, which comprised about $95 \%$ of asbestos used in most Western countries, because of its short half-life in the lung and its limited ability to form asbestos bodies. Subsequently, in Germany the number of accepted lung cancer cases has plateaued at approximately 800 per year for nearly two decades despite the strong linear increase in physician-reported cases amounting to some 5000 annually.

Recently published work by Feder et al. [55] is based on asbestos fiber burden in human lungs and on Roggli's diagnostic modifications; it fits very well with the studies casting doubt on the well-documented adverse health effects of chrysotile. Their non-substantiated claim that chrysotile fibers are persistent in human lung is contradicted by the collective experience of many experienced research groups $[17,18,20-23,70]$ including the Institute for Occupational and Social Medicine at the Justus Liebig University of Giessen, Germany. In the latter 
institute lung specimens of more than 350 patients with and 150 without occupational asbestos exposure were analyzed by scanning and transmission electron microscopy and results were interpreted in combination with a detailed clinical and occupational history [71, 72]. Most striking were very low or even missing fibers after a latency period of more than 25 years. In contrast to this well-funded experience noted earlier, Feder et al. reported SEM or TEM fiber analysis based on only six patients at autopsies. Feder et al.'s publication shows several severe shortcomings. It is not clear from which analytical method fiber data was employed and then presented in the supplementary material. The same is true for asbestosis grading, since the authors mention that they followed different heterogeneous definitions. It is important to note that restrictive, unsubstantiated, modified asbestosis grading according to Roggli et al. [62] in combination with unsound high asbestos body or asbestos fiber threshold concentrations has frequently led to denying well-substantiated compensation claims of asbestos victims [65]. Rather than tissue burden, the Helsinki criteria states a history of exposure should be used.

Another approach of German insurance affiliated pathologists was acceptance of low biopersistence of chrysotile, but falsely interpreting its low concentrations or absence in lung tissue in previously exposed workers as having no relevant pathophysiological effects of disappeared fibers by ignoring likely initial disease-initiating effects $[16,73]$. It is well known that retained lung asbestos does not predict either lung tumor or mesothelioma risk [50], as also noted above.

A publication by La Vecchia and Boffetta [74] was of special relevance for asbestos compensation issues mainly due to chrysotile exposure in Italy. Industry driven, this publication stated that mesothelioma was caused by initial asbestos exposure (frequently occurring in companies that no longer exist) whereas subsequent exposures were of minor or no causative relevance. This wrong assumption was refuted in several letters and commentaries [43, 75-77]. Asbestos does not only act as an initiator, but has been called a promotor as well, and therefore all exposures matter.

\section{Unsound science and policy influence}

An important dimension of science and policy malfeasance has arisen with the infiltration by vested interests of governmental decision-making bodies and regulatory processes for assessing hazards, risks and the need for preventive actions. Examples of such conduct include not only asbestos, but also tobacco, pesticides, climate change and many other issues of commercial interest. All these activities have been part of the industries' campaign to promote their version of 'sound science' and 'good epidemiology' [78-80]. In so doing, corporate interests frequently have inhibited or even blocked legislative solutions ensuring that public-policy is not based on true sound science [81-83]. There are well-studied examples of corporate manipulation and malfeasance by the asbestos industry, which have influenced the results of scientific findings, delayed important knowledge about the asbestos-cancer relationship, and thereby influenced law and public policy to serve their own interests rather than the interests of workers and public health. Supposedly scientifically credible consultants were engaged to cast doubt on adverse health effects, diagnostic criteria and compensation issues; nowadays, the asbestos industry continues this influence $[5,58,60$, $79,84-86$ ] by promoting the unrealistic "safe use" of chrysotile asbestos. Their strategy has successfully prevented its banning in various countries and its listing in the Rotterdam Convention declaration [87]. The asbestos industry has published many "product defense" articles, primarily in industry-orientated toxicology journals, mostly written by scientific consultants and consulting firms, or even by ghostwriters; the practice is very similar to the one previously applied by the tobacco, car, food and other industries. Failure to disclose potential conflicts of interests is common for such papers. An example described by the New York Supreme Court Division is the following: Georgia Pacific (GP; which funded a serious of articles, orchestrated and controlled by lawyers, in an effort to create a product defense together with other companies making and selling asbestos-containing joint compounds), misused these studies in its defense of asbestos-related lawsuits. GP entered into a special employment relationship with its director of the Toxicology and Chemical Management to perform expert consulting services under the auspices of its in-house counsel, who also was significantly involved in the pre-publication review-process [11]. Despite this extensive participation, none of the articles disclosed that GP's in-house counsel had reviewed the manuscripts before they were submitted for publication. Two articles falsely stated that "GP did not participate in the design of the study, analysis of the data or preparation of the manuscript". As the court remarked, it is of concern that GP's in-house counsel would be so intimately involved in supposedly objective scientific studies, especially in light of GP's disclosure denying such participation. The New York court described the consultants' work, mainly published by Bernstein D.M., Berman D.W. and colleagues as "seeding of the scientific literature with GP-funded studies". For more details of this practice including ghostwriting see also $[4,10,11]$.

To further the myth regarding the "apparent safety" of asbestos, and related products, large scale corruption and distortion of scientific literature took place [88-90]. 
As described in detail by Egilman et al. $[89,90]$ and by Michaels [83], asbestos companies have successfully repressed and/or modified the state of the art to cover up the hazards of asbestos.

Egilman et al. [78, 79] particularly addressed the issue of how the asbestos industry and asbestos insurance entities (Metropolitan Life insurance company; MetLife) have influenced compensation laws in numerous states and concocting an arbitrary "protective" standard to monitor asbestos exposure [91]. As stated by Egilman, "MetLife established itself as a public authority in industrial health in the early part of the $20^{\text {th }}$ century, gaining the trust of the public. They were able to use this trust and authority to avoid financial loss, including the firing of sick workers, and avoid legal liability by organizing a network of experts to testify on their behalf in silica- and asbestos-related damage suits. They further manipulated the results of scientific findings from major research institutions, delaying important knowledge about the asbestoscancer relationship" [79].

\section{Discussion}

The above-mentioned publications of corporate affiliates put forth unreliable illness estimates and conclusions by omitting well established scientific facts, relying on incomplete and or outdated data, or omitting critiques of data sets relied upon, and drawing false conclusions due to use of data sets that are not adequately controlled for latency and/or exposure.

There is also the Vanderbilt talc issue-contaminated with asbestos - where a company official boasted to workers of having a "US Senator in our back pocket".

As mentioned, there is absolutely no doubt among independent scientists that all asbestos types are carcinogenic and cause many diseases including mesothelioma. This was also IARC's conclusion upon evaluation of the available literature [92] as well as of other scientific organisations and societies [11, 93-97]. Furthermore, exposure to chrysotile is also associated with the other typical asbestos-caused disorders - asbestosis and plural fibrosis [3, 93-96, 98, 99]. The difference between diseases RRs (risk ratios) of chrysotile versus amphiboles has been debated and is considered by some to be a legitimate but unsettled issue. Some, but not all studies, provide evidence of differences of the various asbestos fiber types. In this connection recent publications by Lenters, Burdorf et al. $[100,101]$ are worth mentioning. These authors had a closer look at the quality of asbestos exposure assessment; they came to the conclusion that differences between risks of chrysotile and amphiboles are mainly due to shortcomings in exposure assessment than in fiber types.

By summarizing the literature, Lemen [102], Frank [11] and Egilman [103] demonstrate that chrysotile meets all of Hill's nine proposed criteria of causation, i.e. of malignant mesothelioma. The same is true for the other asbestos-related cancers and for asbestosis. As for other asbestos types, no threshold could be demonstrated below which adverse health effects do not occur.

As mentioned, the counter argument that amphiboles frequently present in very low amounts in chrysotile products are responsible for the disorders found in exposed workers is not likely because the mostly very low or even absent amphibole contamination does not correlate with diseases. Studies in cohorts only exposed to chrysotile fibers such as from specific mines, textile industries, brake repairing, but not to amphiboles, exhibit the typical asbestos-related diseases, especially mesothelioma [27, 104-109]; see also overviews by Lemen at al [29]. and by Lemen 2004 [102]. Frank et al. [35] analyzed Canadian UICC chrysotile B which is free of tremolite by electron microscopy; they found that chrysotile was the only fibrous asbestos component. Very similar results were reported in miners and millers from Balangero, Italy, [104], China [110] or Zimbabwe [106] exposed to amphibole-free chrysotile. In the former East Germany Republic DDR where much Russian chrysotile was used [said to be amphibole free], and sometimes only chrysotile was applied, hundreds of pleural and peritoneal mesotheliomas were recorded and written about [111]. These findings correspond to chrysotile-induced pathology in animal studies which do not support an explanation based on the so-called "amphibole hypothesis". The animal experiments showed that pure chrysotile is carcinogenic [37, 38, 112-119]. Also in-vitro toxicological studies provided corresponding findings [103].

The aforementioned well-founded outcomes of human and animal studies on adverse health effects of chrysotile as published by the IARC [92], the Collegium Ramazzini [120], and other authors [27, 35, 53, 99, 101, 102, 115, 121-126] were all not cited in recent publications questioning these facts $[8,30,31,127]$. It has also been ignored that chrysotile, especially its short fibers, move to the pleura where high concentrations can be found in exposed subjects and animals, often with no presence of amphiboles [21, 117, 128-131].

With regard to causative asbestos exposure, it is important that the level of exposure necessary to induce mesothelioma is well below the level necessary to induce asbestosis or other non-malignant asbestos-associated diseases [95]. So it is not surprising that mesotheliomas have been documented not only in occupational settings but also in para-occupational settings such as those occurring among family members exposed to asbestos fibers introduced into the household through the clothes of the worker, and in the vicinity of asbestos manufacturing plants where fiber concentrations are much lower [40, 132-134]. 
However, it should be mentioned that none of the efforts to use statistical models to characterize relative cancer potencies for asbestos fiber types and sizes have been able to overcome limitations of the exposure data. Quantification of the risk is not reliable because accurate exposure information is lacking for the epidemiological studies used such as Hodgson \& Darnton [32] and Berman \& Crump [33, 34]. Hodgson \& Darnton [135] explained that they relied on "guesstimate(s)" for a number of missing data points [50]. By only referring to studies of earlier potency estimates reported by Hodgson and Darnton [32].

The significantly revised later estimates lowering the potency differences between chrysotile and amphibole asbestos by these same authors (Hodgson and Darnton [135] have been repeatedly ignored as already pointed out by (Lemen, Frank et al. [29]. Resulting uncertainties have been so great that estimates should not be used to drive occupational and environmental health policy. The EPA rejected and discontinued work on its proposed methods for estimating potency factors. For more details see the EPA Report on the Peer Consultation Workshop to Discuss a Proposed Protocol to Assess AsbestosRelated Risk, at pages 3--14.: "The risk coefficients (for mesothelioma) were largely derived from data sets with inadequate exposure--response information for mesothelioma, and assumptions had to be made to determine critical inputs to the mesothelioma model (e.g., average exposure, duration of exposure)".

Correspondingly, according to Silverstein, et al. [136], an EPA Peer Consultation Workshop convened to review the 2003 version of the Berman \& Crump approach yielded the following criticisms: "The 2003 report repeated earlier cautions that grossly imperfect exposure characterization in the epidemiology studies creates substantial uncertainties in the estimation of potency factors, including both random and systematic biases. Among the specific data flaws mentioned were unrepresentative sampling strategies, use of surrogate measures in the absence of actual asbestos measure [136].

\section{Conclusions}

The ongoing promotion of chrysotile combined with unjustified downplaying of its adverse health effects, especially of its carcinogenicity, is driven by commercial interests and is not supported by scientific evidence, see e.g. websites of ICA and its predecessor the Chrysotile Institute [137, 138] and a related commentary [4]. The same is true for widespread restrictive compensation practices based upon lung fiber counts or inadequate risk models [139-141]. As an example, the aforementioned statement of predominantly non-asbestos causation of mesothelioma in women in a chapter in the WHO/IARC book accompanied by similarly distorted statements made by the same or other sponsored or affiliated authors in various journals, lacks scientific evidence and is not true.

A related example is the "amphibole hypothesis" originating from the Quebec industry-sponsored studies. Correspondingly, McCormack et al. [28] and Gilham et al. $[13,142]$ published that figures showing mesotheliomas related to chrysotile asbestos exposure may be erroneously overestimated, and that mesothelioma in chrysotile-exposed cohorts is due to other asbestos types. As mentioned, the literature shows the opposite $[35,37,92,143]$.

The relative lack of chrysotile biopersistence in the lung combined with its translocation to the pleura and also to the peritoneum and pericardium where the mesothelioma develops has to be taken into consideration when interpreting fiber data in tissue and pathogenicity [24, 128, 131, 144].

The aforementioned influence of vested asbestos-related interests in workers and public health issues including regulations and compensation necessitate ongoing alertness, corrections and appropriate reactions in scientific as well as public media and policy advisory bodies.

It should be mentioned that in general sophisticated mineralogical analysis of lung tissue is a useful method for determining the lung fiber burden when the occupational history does not allow a reliable exposure assessment. However, it has to be taken into consideration that there is considerable interlaboratory variation and it is essential that each laboratory establishes its own reference values [63]. Thus, comparison of data obtained in different laboratories is difficult and this limits the proper use of mineralogical results in the legal field. Furthermore, as stated in the Helsinki criteria [63] at negative non-effect outcome excludes neither potential past asbestos exposure nor the likelihood of asbestos-related disease to develop, while with positive results the possibility of a serious health consequence is increased [145].

\section{Acknowledgements \\ The authors thank Kathleen Ruff for providing available citable data from here website https://rightoncanada.ca/ and additional relevant information.}

Adherence to national and international regulations Not applicable.

Ethics declarations

Not applicable.

Additional information

No funds were received for the preparation of this work.

Authors' contributions

XB planed the work and developed a first draft. ALF analysed and complemented the draft and contributed in writing the final manuscript. Both authors read and approved the final manuscript.

Funding

No funding was received for this study. 


\section{Availability of data and materials}

Not applicable.

\section{Ethics approval and consent to participate}

Not applicable.

\section{Consent for publication}

Not applicable.

\section{Competing interests}

XB has prepared medical expert opinions for German social courts and statutory accident institutions. ALF regularly testifies in asbestos litigations, primarily for plaintiffs. The authors declare that they have no other competing interests.

\section{Author details}

${ }^{1}$ Chair Em. of Occupational Medicine, University of Hamburg, Hamburg, Germany. ${ }^{2}$ European Society for Environmental and Occupational Medicine, P.O. Box 370514, D-14135 Berlin, Germany. ${ }^{3}$ Chair Em. of Environmental \& Occupational Health, Drexel University School of Public Health, Philadelphia, PA, USA.

Received: 1 October 2020 Accepted: 9 February 2021

Published online: 23 February 2021

\section{References}

1. Ruff K. Exposé of the International Chrysotile Association: The International Chrysotile Association Continues Its Deadly Work Around The World 2013 [Available from: https://rightoncanada.ca/?p=1862.

2. Ruff K. Scientists ask Quebec government to stop deadly misconduct by international asbestos lobby based in Quebec 2019 [Available from: https:// rightoncanada.ca/?p=4400.

3. Welch LS. Asbestos exposure causes mesothelioma, but not this asbestos exposure: an amicus brief to the Michigan supreme court. Int J Occup Environ Health. 2007;13(3):318-27.

4. Baur X, Soskolne CL, Lemen RA, Schneider J, Woitowitz HJ, Budnik LT. How conflicted authors undermine the World Health Organization (WHO) campaign to stop all use of asbestos: spotlight on studies showing that chrysotile is carcinogenic and facilitates other non-cancer asbestos-related diseases. Int J Occup Environ Health. 2015;21(2):176-9.

5. Egilman D, Fehnel C, Bohme SR. Exposing the "myth" of ABC, "anything but chrysotile": a critique of the Canadian asbestos mining industry and McGill University chrysotile studies. Am J Ind Med. 2003;44(5):540-57.

6. Lemen RA. Asbestos in brakes: exposure and risk of disease. Am J Ind Med. 2004:45(3):229-37.

7. Egilman D, Howe S. Against anti-health epidemiology: corporate obstruction of public health via manipulation of epidemiology. Int J Occup Environ Health. 2007;13(1):118-24.

8. Bernstein DM. The health risk of chrysotile asbestos. Curr Opin Pulm Med. 2014;20(4):366-70

9. Roggli VL. The so-called short-fiber controversy: literature review and critical analysis. Archives of pathology \& laboratory medicine. 2015;139(8):1052-7.

10. Ruff K. Scientific journals and conflict of interest disclosure: what progress been made? Environmental Health [Internet]. 2015; 14(45). Available from: http://dx.doi.org/https://doi.org/10.1186/s12940-015-0035-6

11. Affidavit of Arthur L. Frank, State of Pennsylvania County of Philadelphia [Internet]. State of Pennsylvania County of Philadelphia. 2016. Available from: https://drexel.edu/dornsife/academics/faculty/Arthur\%20Frank/.

12. Ruff K. Longtime asbestos industry consultant, David Bernstein, discloses his industry ties 2014 [Available from: https://rightoncanada.ca/?p=2672.

13. Gilham C, Rake C, Burdett G, Nicholson AG, Davison L, Franchini A, et al. Pleural mesothelioma and lung cancer risks in relation to occupational history and asbestos lung burden. Occup Environ Med. 2016;73(5):290-9.

14. Ruff K. Asbestos lobby hopes to block asbestos bans with its bought science 2017 [Available from: https://rightoncanada.ca/?p=3926.

15. Barrett JC. Cellular and molecular mechanisms of asbestos carcinogenicity: implications for biopersistence. Environ Health Perspect. 1994;102(Suppl 5):19-23.

16. Egilman D, Baur X, Soskolne CL. Unreliable proposed 'new standard' for assessing asbestos exposure. Occup Environ Med. 2016;73(10):709.
17. Baker DB. Limitations in drawing etiologic inferences based on measurement of asbestos fibers from lung tissue. Ann N Y Acad Sci. 1991; 643:61-70.

18. Churg A, Wright JL. Persistence of natural mineral fibers in human lungs: an overview. Environ Health Perspect. 1994;102(Suppl 5):229-33.

19. Dodson RF, Hammar SP, Poye LW. A technical comparison of evaluating asbestos concentration by phase-contrast microscopy (PCM), scanning electron microscopy (SEM), and analytical transmission electron microscopy (ATEM) as illustrated from data generated from a case report. Inhal Toxicol. 2008;20(7):723-32

20. Finkelstein MM, Dufresne A. Inferences on the kinetics of asbestos deposition and clearance among chrysotile miners and millers. Am J Ind Med. 1999:35(4):401-12.

21. Kohyama N, Suzuki Y. Analysis of asbestos fibers in lung parenchyma, pleural plaques, and mesothelioma tissues of north American insulation workers. Ann N Y Acad Sci. 1991;643:27-52.

22. Suzuki Y, Yuen SR. Asbestos fibers contributing to the induction of human malignant mesothelioma. Ann N Y Acad Sci. 2002;982:160-76.

23. Wagner JC, Berry G, Pooley FD. Mesotheliomas and asbestos type in asbestos textile workers: a study of lung contents. Br Med J. 1982;285(6342): 603-6.

24. Suzuki Y, Yuen SR, Ashley R. Short, thin asbestos fibers contribute to the development of human malignant mesothelioma: pathological evidence. Int J Hyg Environ Health. 2005;208(3):201-10.

25. Abraham JL. Analysis of fibrous and non-fibrous particles. Environmental and occupational medicine, 4th edition. Philadelphia, USA: Lippincott Williams and Wilkins; 2006. p. 277-97.

26. Dodson RF, Atkinson MA, Levin JL. Asbestos fiber length as related to potential pathogenicity: a critical review. Am J Ind Med. 2003;44(3):291-7.

27. Egilman D, Bird T. Short fiber tremolite free chrysotile mesothelioma cohort revealed. Am J Ind Med. 2016;59(3):196-9.

28. McCormack V, Peto J, Byrnes G, Straif K, Boffetta P. Estimating the asbestosrelated lung cancer burden from mesothelioma mortality. Br J Cancer. 2012; 106(3):575-84

29. Lemen RA, Frank AL, Soskolne CL, Weiss SH, Castleman B. Comment on 'estimating the asbestos-related lung cancer burden from mesothelioma mortality' - IARC and chrysotile risks. Br J Cancer. 2013;109(3):823-5.

30. Attanoos RL, Churg A, Galateau-Salle F, Gibbs AR, Roggli VL. Malignant mesothelioma and its non-Asbestos causes. Archives of pathology \& laboratory medicine. 2018;142(6):753-60.

31. Gallateau-Salle F, Churg A, Roggli VL, Attanoos R, Borczuk A, Cagle P, et al. Mesothelial tumours - Diffuse malignant mesothelioma - epithelioid mesothelioma.https://pwhdtrial.sharefile.com/d-s28cddf934ff4bd58 In: Travis WD, Brambilla E, Burke AP, Marx A, Nicholson AG, editors. WHO Classification of Tumours of the Lung, Pleura, Thymus and Heart. 4 ed. Lyon: IARCMHO; 2015. p. 156-64.

32. Hodgson JT, Darnton A. The quantitative risks of mesothelioma and lung cancer in relation to asbestos exposure. The Annals of occupational hygiene. 2000;44(8):565-601.

33. Berman DW, Crump KS. Final draft: technical support document for a protocol to assess asbestos-related risk. EPA Report 9345.4 )6. Office of Solid Waste Emergency Response. EPA Report 93454-06 [Internet]. 2003. Available from: bwcase.tripod.com/atech1.pdf.

34. Berman DW, Crump KS. Update of potency factors for asbestos-related lung cancer and mesothelioma. Crit Rev Toxicol. 2008;38(Suppl 1):1-47.

35. Frank AL, Dodson RF, Williams MG. Carcinogenic implications of the lack of tremolite in UICC reference chrysotile. Am J Ind Med. 1998;34(4):314-7.

36. Peto J, Seidman H, Selikoff IJ. Mesothelioma mortality in asbestos workers: implications for models of carcinogenesis and risk assessment. Br J Cancer. 1982:45(1):124-35.

37. Wagner JC, Berry G, Skidmore JW, Timbrell V. The effects of the inhalation of asbestos in rats. Br J Cancer. 1974:29(3):252-69.

38. Pott F, Huth F, Friedrichs KH. Tumorigenic effect of fibrous dust in experimental animals. Environ Health Perspect. 1974:9:313-5.

39. Pavlisko EN, Liu B, Green C, Sporn TA, Roggli VL. Malignant diffuse mesothelioma in women: a study of 354 cases. Am J Surg Pathol. 2020; 44(3):293-304

40. Marsh GM, Benson SM. Response to: 'Pleural mesothelioma and occupational and non-occupational asbestos exposure: a case-control study with quantitative risk assessment' by Ferrante et al. Occup Environ Med. 2017;74(2):156-7. 
41. Lemen RA, Landrigan PJ. Toward an Asbestos Ban in the United States. Int J Environ Res Public Health. 2017;14(11).

42. Ferrante D, Mirabelli D, Tunesi S, Terracini B, Magnani C. Pleural mesothelioma and asbestos exposure: a case-control study with quantitative risk assessment-response to Marsh and Benson's letter. Occup Environ Med. 2017;74(2):157-8.

43. Lemen RA. Mesothelioma from asbestos exposures: epidemiologic patterns and impact in the United States. J Toxicol Environ Health B Crit Rev. 2016; 19(5-6):250-65.

44. Azuma K, Uchiyama I, Chiba Y, Okumura J. Mesothelioma risk and environmental exposure to asbestos: past and future trends in Japan. Int J Occup Environ Health. 2009;15(2):166-72.

45. Davis JM, Addison J, Bolton RE, Donaldson K, Jones AD, Smith T. The pathogenicity of long versus short fibre samples of amosite asbestos administered to rats by inhalation and intraperitoneal injection. $\mathrm{Br} J$ Exp Pathol. 1986;67(3):415-30.

46. Roggli VL, Brody AR. Changes in numbers and dimensions of chrysotile asbestos fibers in lungs of rats following short-term exposure. Exp Lung Res. 1984;7(2):133-47.

47. Yeager H Jr, Russo DA, Yanez M, Gerardi D, Nolan RP, Kagan E, et al. Cytotoxicity of a short-fiber chrysotile asbestos for human alveolar macrophages: preliminary observations. Environ Res. 1983;30(1):224-32.

48. Roggli VL. Testimony in the Case of Michelle and Joseph Zierer Vs. Advance Stores Company, Inc. 2015.

49. Deposition of Victor Louis Roggli: Hearing before the Circuit Court of Kanawha County West Virginia (October 20, 2015, 2015).

50. Egilman D. Fiber types, asbestos potency, and environmental causation: a peer review of published work and legal and regulatory scientific testimony. Int J Occup Environ Health. 2009:15(2):202-28.

51. Finkelstein MM. Asbestos fibre concentrations in the lungs of brake workers: another look. The Annals of occupational hygiene. 2008;52(6):455-61.

52. Roggli VL, Vollmer RT, Butnor KJ, Sporn TA. Tremolite and mesothelioma. The Annals of occupational hygiene. 2002;46(5):447-53.

53. Lemen RA. Chrysotile asbestos and mesothelioma. Environ Health Perspect. 2010;118(7):A282.

54. Feder IS, Theile A, Tannapfel A. Histological findings and lung dust analysis as the basis for occupational disease compensation in asbestos-related lung cancer in Germany. Int J Occup Med Environ Health. 2018;31(3):293-305.

55. Feder IS, Tischoff I, Theile A, Schmitz I, Merget R, Tannapfel A. The asbestos fibre burden in human lungs: new insights into the chrysotile debate. Eur Respir J. 2017:49(6).

56. Baur X. Response to the letter of R. Merget, I. Feder and A. Tannapfel http:// www.ncbi.nlm.nih.gov/pubmed/28222480. Pneumologie [internet]. 2017 Feb; 71(2):[121-3 pp.]. Available from: http://www.ncbi.n/m.nih.gov/ pubmed/28222480.

57. Ruff K. Commentary on "The asbestos fibre burden in human lungs: new insights into the chrysotile debate" by Federet al. in press. 2019.

58. Oliver LC, Belpoggi F, Budnik LT, Egilman D, Frank AL, Mandrioli D, et al. Correspondence regarding the article "The asbestos fibre burden in human lungs: new insights into the chrysotile debate". Eur Respir J. 2017;50(6).

59. Baur X, Belpoggi F, Budnik LT, Casteleyn L, Frank AL, Oliver LC, et al. Letter to the editor (February 14,2018 ) concerning the paper "histological findings and lung dust analysis as the basis for occupational disease compensation in asbestos-related lung cancer in Germany". Int J Occup Med Environ Health. 2018;31(6):837-9.

60. Woitowitz HJ, Baur X. Misleading "new insights into the Chrysotile debate". Pneumologie. 2018;72(7):507-13.

61. Landrigan PJ, Lemen RA, Collegium RO. Letter to the editor (April 4, 2018) concerning the paper "histological findings and lung dust analysis as the basis for occupational disease compensation in asbestos-related lung cancer in Germany". Int J Occup Med Environ Health. 2018;31(6):845-7.

62. Roggli VL, Gibbs AR, Attanoos R, Churg A, Popper H, Cagle P, et al. Pathology of asbestosis- an update of the diagnostic criteria: report of the asbestosis committee of the college of american pathologists and pulmonary pathology society. Archives of pathology \& laboratory medicine. 2010;134(3):462-80.

63. Wolff H, Vehmas T, Oksa P, Rantanen J, Vainio H. Asbestos, asbestosis, and cancer, the Helsinki criteria for diagnosis and attribution 2014: recommendations. Scand J Work Environ Health. 2015;41(1):5-15.
64. Case No. 793085 Plaintiffs, -v- Ammco Tools, Inc., et al.,Defendants. Transcript of proceedings, April 18, 2014. The Court of Common Pleas, Civil Division. The State of Ohio, County of Cuyahoga; 2014.

65. Baur X. Asbestos: socio-legal and scientific controversies and unsound science in the context of the worldwide Asbestos tragedy - lessons to be learned. Pneumologie. 2016;70(6):405-12.

66. Hammar SP, Abraham JL. Commentary on pathologic diagnosis of asbestosis and critique of the 2010 asbestosis Committee of the College of American pathologists (CAP) and pulmonary pathology Society's (PPS) update on the diagnostic criteria for pathologic asbestosis. Am J Ind Med. 2015;58(10):1034-9.

67. No. 63-CIV-2016-812-3. Hendrix K.A. vs. Akebond Brake Co, Et. Arkansas, USA: In the Circuit Court of Saline County, Arkansas City Division; 2018.

68. Baur X, Woitowitz HJ, Budnik LT, Egilman D, Oliver C, Frank A, et al. Asbestos, asbestosis, and cancer: the Helsinki criteria for diagnosis and attribution. Critical need for revision of the 2014 update. Am J Ind Med. 2017:60(5):411-21.

69. Egilman D, Tran T. A commentary on Roggli's "the so-called short-Fiber controversy". Int J Occup Environ Health. 2016;22(3):181-6.

70. Roggli VL, Sharma A, Butnor KJ, Sporn T, Vollmer RT. Malignant mesothelioma and occupational exposure to asbestos: a clinicopathological correlation of 1445 cases. Ultrastruct Pathol. 2002;26(2):55-65.

71. Schneider J, Arhelger R, Brueckel B. Lungenstaubanalysen in der Begutachtung asbestverursachter Erkrankungen. Zbl Arbeitsmed. 2015; 65:305-9.

72. Schneider J, Arhelger R, Brueckel B. Leserbriefantwort zum Artikel Lungenstaubanalysen in der Begutachtung asbestverursachter Erkrankungen. Zbl Arbeitsmed. 2016;4:228-31.

73. Baur X, Woitowitz HJ. Lung Cancer as an occupational disease. Pneumologie. 2016;70(8):510-3.

74. La Vecchia C, Boffetta P. Role of stopping exposure and recent exposure to asbestos in the risk of mesothelioma. Eur J Cancer Prev. 2012;21(3):227-30.

75. Baur X, Terracini B, Belpoggi F, Budnik LT, Woitowitz HJ, Soskolne CL. Commentary to the article lung function not affected by asbestos exposure in workers with normal computed tomography scan, by Schikowsky, Felten, et al., 2017. Am J Ind Med. 2018;61(4):351-4.

76. Terracini B, Mirabelli D, Baur X, Landrigan PJ, Ramazzini C. Re: comments on the causation of malignant mesothelioma: rebutting the false concept that recent exposures to asbestos do not contribute to causation of mesothelioma. Am J Ind Med. 2016;59(12):1180-2.

77. Magnani C, Fubini B, Mirabelli D, Bertazzi PA, Bianchi C, Chellini E, et al. Pleural mesothelioma: epidemiological and public health issues. Report from the second Italian consensus conference on pleural mesothelioma. La Medicina del lavoro. 2013;104(3):191-202

78. Egilman D, Bird T, Lee C. Dust diseases and the legacy of corporate manipulation of science and law. Int J Occup Environ Health. 2014;20(2): $115-25$.

79. Egilman DS, Bird T, Lee C. MetLife and its corporate allies: dust diseases and the manipulation of science. Int J Occup Environ Health. 2013;19(4):287-303.

80. Baur X, Budnik LT, Ruff K, Egilman DS, Lemen RA, Soskolne CL. Ethics, morality, and conflicting interests: how questionable professional integrity in some scientists supports global corporate influence in public health. Int J Occup Environ Health. 2015:21(2):172-5.

81. Greenberg DS. Science, money, and politics: political triumph and ethical erosion. Chicago: The University Chicago Press; 2001.

82. Baba A, Cook DM, McGarity TO, Bero LA. Legislating "sound science": the role of the tobacco industry. Am J Public Health. 2005;95(Suppl 1):S20-7.

83. Michaels D. The triumph of doubt: dark money and the science of deception. New York, USA: Oxford University Press; 2020

84. Pezerat H. Chrysotile biopersistence: the misuse of biased studies. Int J Occup Environ Health. 2009;15(1):102-6.

85. Bohme SR. Expression of concern: false claim to be free of conflicts in asbestos biopersistence debate. Int J Occup Environ Health. 2012;18(2):85-8.

86. Michaels D. Doubt is their product: how industry's assault on science threatens your health. New York, USA: Oxford University Press; 2008.

87. Ruff K. Asbestos industry sabotages UN Rotterdam Convention https:// rightoncanada.ca/?p=4027May 4, 2017 accessed August 28, 2019.

88. Kazan-Allen L. The asbestos war. Int J Occup Environ Health. 2003; 9(3):173-93. 
89. Egilman D, Wallace W, Hom C. Corporate corruption of medical literature: asbestos studies concealed by W.R. Grace \& co. Account Res. 1998;6(1-2):127-47.

90. Egilman DS, Reinert A. Corruption of previously published asbestos research. Arch Environ Health. 2000;55(1):75-6.

91. (WHO) TIPoCSIWHO. Environmental Health Criteria 203 - Chrysotile Asbestos. 1998.

92. IARC. asbestos (Chrysotile, Amosite, Crocidolite, Tremolite, Actinolite and Anthophyllite) http://monographs.iarc.fr/ENG/Monographs/vol100C/. IARC Monographs on the Evaluation of Carcinogenic Risks to Humans [Internet]. 2012; 100C. A Review of Human Carcinogens: Arsenic, Metals, Fibres, and Dusts.

93. American Thoracic S. Diagnosis and initial management of nonmalignant diseases related to asbestos. Am J Respir Crit Care Med. 2004;170(6):691-715.

94. Loomis D, Dement J, Richardson D, Wolf S. Asbestos fibre dimensions and lung cancer mortality among workers exposed to chrysotile. Occup Environ Med. 2010;67(9):580-4.

95. IPCS. Environmental Health Criteria 203 Chrysotile Asbestos. WHO. 1998

96. ATSDR. Public Health Statement for Asbestos https://www.atsdr.cdc.gov/ PHS/PHS.asp?id=28\&tid=42001 [cited 2001

97. IARC. IARC Monographs on the Evaluation of Carcinogenic Risks to Humans. http://www.iarc.fr/en/media-centre/iarcnews/2012/mono105-info.php. Lyon, France: WHO; 2012. Available from: http://www.iarc.fr/en/media-centre/ia rcnews/2012/mono105-info.php.

98. IJPC. http://www.ijpc-se.org/documents/01.JPC-SE-Position_Statement_on_A sbestos-June_4_2012-Summary_and_Appendix_A_English.pdf. 2012

99. Baur X, Schneider J, Woitowitz HJ, Velasco GM. Do adverse health effects of chrysotile and amphibole asbestos differ? Pneumologie. 2012;66(8):497-506.

100. Lenters $V$, Vermeulen R, Dogger S, Stayner L, Portengen L, Burdorf A, et al. A meta-analysis of asbestos and lung cancer: is better quality exposure assessment associated with steeper slopes of the exposure-response relationships? Environ Health Perspect. 2011;119(11):1547-55.

101. Lenters V, Burdorf A, Vermeulen R, Stayner L, Heederik D. Quality of evidence must guide risk assessment of asbestos. The Annals of occupational hygiene. 2012;56(8):879-87.

102. Lemen RA. Chrysotile asbestos as a cause of mesothelioma: application of the hill causation model. Int J Occup Environ Health. 2004;10(2):233-9.

103. State of Massechusetts. County of Norfolk. Chrysotile Affidavit of David S. Egilman. 2011.

104. Ferrante D, Mirabelli D, Silvestri S, Azzolina D, Giovannini A, Tribaudino P, et al. Mortality and mesothelioma incidence among chrysotile asbestos miners in Balangero, Italy: A cohort study. AJIM. 2019.

105. Mirabelli D, Calisti R, Barone-Adesi F, Fornero E, Merletti F, Magnani C. Excess of mesotheliomas after exposure to chrysotile in Balangero, Italy. Occup Environ Med. 2008;65(12):815-9.

106. Cullen M, Baloyi R. Chrysotile asbestos and health in Zimbabwe: I. analysis of miners and millers compensated for asbestos-related diseases since independence 1980. Am J Ind Med. 1991;19:161-9.

107. Sturm W, Menze B, Krause J, Thriene B. Use of asbestos, health risks and induced occupational diseases in the former East Germany. Toxicol Lets. 1994;72:317-24.

108. Robinson CF, Lemen RA, Wagoner JK. Mortality patterns, 1940-1975 among workers employed in an asbestos textile friction and packing products manufacturing facilities. In: Lemen RA, Dement JM, editors. Dust and disease. Park Forest, IL: Pathotox; 1979. p. 131-43.

109. Leigh J, Driscoll T. Malignant mesothelioma in Australia, 1945-2002. Int J Occup Environ Health. 2003;9:206.

110. Yano E, Wang ZM, Wang XR, Wang MZ, Lan YJ. Cancer mortality among workers exposed to amphibole-free chrysotile asbestos. Am J Epidemiol. 2001:154(6):538-43.

111. BAuA. National asbestos profile for Germany. https://www.baua.de/EN/ Service/Publications/Report/Gd80.html 2014. Available from: https://www.ba ua.de/EN/Service/Publications/Report/Gd80.htm

112. Bolton RE, Davis JM, Donaldson K, Wright A. Variations in the carcinogenicity of mineral fibres. The Annals of occupational hygiene. 1982; 26(1-4):569-82.

113. Minardi F, Maltoni $C$. Results of recent experimental research on the carcinogenicity of natural and modified asbestos. Ann N Y Acad Sci. 1988; 534:754-61.
114. Roller M, Pott F, Kamino K, Althoff GH, Bellmann B. Dose-response relationship of fibrous dusts in intraperitoneal studies. Environ Health Perspect. 1997;105(Suppl 5):1253-6.

115. Wagner JC, Berry G, Skidmore JW, Pooley FD. The comparative effects of three chrysotiles by injection and inhalation in rats. IARC Sci Publ. 1980;30: 363-72.

116. Davis JM, Jones AD. Comparisons of the pathogenicity of long and short fibres of chrysotile asbestos in rats. Br J Exp Pathol. 1988;69(5):717-37.

117. McDonald JC, Armstrong B, Case B, Doell D, McCaughey WT, McDonald AD, et al. Mesothelioma and asbestos fiber type. Evidence from lung tissue analyses. Cancer. 1989;63(8):1544-7.

118. Kogan FM, Vanchugova NN, Frasch VN. Possibility of inducing glandular stomach cancer in rats exposed to asbestos. $\mathrm{Br} \mathrm{J}$ Ind Med. 1987;44(10):682-6.

119. Pott F. Neoplastic findings in experimental asbestos studies and conclusions for fiber carcinogenesis in humans. Ann N Y Acad Sci. 1991;643:205-18.

120. Collegium-Ramazzini. The 18th Collegium Ramazzini statement: The global health dimensions of asbestos and asbestos-related diseases. Scandinavian journal of work, environment \& health. 2016:42(1):86-90.

121. Davis JM, Coniam SW. Experimental studies on the effects of heated chrysotile asbestos and automobile brake lining dust injected into the body cavities of mice. Exp Mol Pathol. 1973;19(3):339-53.

122. Woitowitz H-J, Rödelsperger K. Chrysotile Asbestos and mesothelioma. Am J Ind Med. 1991;19(4):551-3.

123. Pott F. Asbestos use and carcinogenicity in Germany and a comparison with animal studies. The Annals of occupational hygiene. 1994;38(4):589600420.

124. Lemen RA. Asbestos related disease in the United States. La Medicina del lavoro. 1995;86(5):411-25.

125. Stayner LT, Dankovic DA, Lemen RA. Occupational exposure to chrysotile asbestos and cancer risk: a review of the amphibole hypothesis. Am J Public Health. 1996:86(2):179-86.

126. Wang $X$, Yano E, Lin S, Yu IT, Lan Y, Tse LA, et al. Cancer mortality in Chinese chrysotile asbestos miners: exposure-response relationships. PLoS One. 2013;8(8):e71899.

127. Bernstein DM, Rogers RA, Sepulveda R, Kunzendorf P, Bellmann B, Ernst H, et al. Evaluation of the fate and pathological response in the lung and pleura of brake dust alone and in combination with added chrysotile compared to crocidolite asbestos following short-term inhalation exposure. Toxicol Appl Pharmacol. 2015;283(1):20-34.

128. Suzuki Y, Yuen SR. Asbestos tissue burden study on human malignant mesothelioma. Ind Health. 2001:39(2):150-60.

129. Bignon J, Brochard P, Sebastien P. Asbestos pathology: clinical aspects epidemiological data and prevention. Schweiz Med Wochenschr. 1982; 112(6):177-85.

130. Dodson RF, Atkinson MA. Measurements of asbestos burden in tissues. Ann N Y Acad Sci. 2006;1076:281-91.

131. Sebastien P, Janson X, Gaudichet A, Hirsch A, Bignon J. Asbestos retention in human respiratory tissues: comparative measurements in lung parenchyma and in parietal pleura. IARC Sci Publ. 1980;30:237-46.

132. NIOSH. Report to congress on workers' home contamination study conducted under the workers' family protection act (29 U.S.C. 671a). Cincinnati,Ohio: U.S.Department ofHealth and Human Services, Public Health Service, Centers for Disease Control and Prevention, National Institute for Occupational Safety and Health; 1995.

133. Finkelstein MM. Reanalysis of non-occupational exposure to asbestos and the risk of pleural mesothelioma. Occup Environ Med. 2018;75(6):472-3.

134. Finkelstein MM. Malignant mesothelioma and its nonasbestos causes. Archives of pathology \& laboratory medicine. 2019:143(6):659-60.

135. Hodgson JT, Darnton A. Mesothelioma risk from chrysotile. Occup Environ Med. 2010;67(6):432.

136. Silverstein MA, Welch LS, Lemen R. Developments in asbestos cancer risk assessment. Am J Ind Med. 2009:52(11):850-8.

137. ICA. For environmental occupational health safe and responsible use 2020 [Available from: https://chrysotileassociation.com/news/n_list.php.

138. ICA. For environmental occupational health safe and responsible use [Available from: https://chrysotileassociation.com/about.php.

139. Woitowitz $\mathrm{H}-\mathrm{J}$, Baur X. Asbestos-induced lung cancer in Germany: is the compensation practice, in accordance with the epidemiological findings? Collegium Ramazzini, annual Ramazzini days; Carpi, Italy2014. 
140. Baur X. Asbestos-Related Disorders in Germany: Background, Politics, Incidence, Diagnostics and Compensation. Int J Environ Res Public Health. 2018;15(1).

141. Terracini B, Mirabelli D, Baur X, Landrigan P, Collegium R. Comments on the causation of malignant mesothelioma: rebutting the false concept that recent exposures to asbestos do not contribute to causation of mesothelioma. Am J Ind Med. 2016;59(6):506-7.

142. Gilham C, Rake C, Hodgson J, Darnton A, Burdett G, Peto Wild J, et al. Past and current asbestos exposure and future mesothelioma risks in Britain: the inhaled particles study (TIPS). Int J Epidemiol. 2018;47(6):1745-56.

143. Straif K, Benbrahim-Tallaa L, Baan R, Grosse Y, Secretan B, El Ghissassi F, et al. A review of human carcinogens--part C: metals, arsenic, dusts, and fibres. Lancet Oncol. 2009:10(5):453-4.

144. Dodson RF, Williams MG Jr, Corn CJ, Brollo A, Bianchi C. Asbestos content of lung tissue, lymph nodes, and pleural plaques from former shipyard workers. Am Rev Respir Dis. 1990;142(4):843-7.

145. Vainio H. Epidemics of asbestos-related diseases--something old, something new. Scand J Work Environ Health. 2015;41(1):1-4.

\section{Publisher's Note}

Springer Nature remains neutral with regard to jurisdictional claims in published maps and institutional affiliations [14].

Ready to submit your research? Choose BMC and benefit from:

- fast, convenient online submission

- thorough peer review by experienced researchers in your field

- rapid publication on acceptance

- support for research data, including large and complex data types

- gold Open Access which fosters wider collaboration and increased citations

- maximum visibility for your research: over $100 \mathrm{M}$ website views per year

At $\mathrm{BMC}$, research is always in progress.

Learn more biomedcentral.com/submissions 